\title{
ANALISIS FAKTOR - FAKTOR YANG MEMPENGARUHI AUDIT JUDGEMENT PADA PERUSAHAAN KONSULTAN BISNIS KECIL DI TANGERANG
}

\author{
Priscillia Sharon \\ Universitas Multimedia Nusantara \\ priscilliasharon@gmail.com
}

\begin{abstract}
Audit Judgement is one of important aspect in Accounting Consulting Business. Audit Judgement create expectation and trust between corporate and reader of Financial Report. It is really important to understand the flow and how Audit Judgement can be derived. Purpose of this research is to "revisit" all possible factor that could affect audit judgement in small and new business consultant firm in Tangerang. The author aim to understand more about audit judgement and hope could find same factor in small firm case.

Finding of this research confirm that there is influence of audit experience and pressure toward obedience. This research use F test, $t$ test and $R^{2}$ to valuate research model. Pressure toward obedience has negative relationship with audit judgement. Researcher conclude that in small firm case, most of high level executive try their best to conduct ethical behavior and make sure they can perform best services for their clients. While in lower level, most of junior still obey their leader or their clients. But sometimes it caused confusion because the clients objective not always the same as the top executive objective. So in the end, the top level could maintain their standard and researcher suggest they could create standard code of conduct in their office, so at junior level, they could learn be more professional base on ethical behavior.
\end{abstract}

Keyword : Audit-Judgement, Accounting Consulting Business, Pressure toward Obedience, Gender, Audit-Experience, Multiple Regression.

\section{PENDAHULUAN}

Akuntan publik merupakan profesi yang sangat penting dalam menunjang aktivitas bisnis. Profesi ini menuntut ketekunan dan ketelitian dalam melaksanakan proses audit yang panjang dan melelahkan. Jasa yang diberikan oleh kantor akuntan publik merupakan jasa yang bersifat assurance dengan tujuan memberikan opini dan pertimbangan yang baik bagi pengguna laporan keuangan. Untuk melaksanakan tugasnya seorang auditor tetap harus berpegang teguh pada prinsip-prinsip akuntansi dan juga kode etik profesi mereka. Sudah sewajarnya para auditor harus memberikan opini dengan sejujurjujurnya dan berpendapat apa adanya aja kewajaran laporan keuangan yang dibuat. Profesi ini sendiri erat kaitannya dengan kepercayaan publik dan menjadi sangat penting belakangan ini.

Semenjak skandal kasus Enron yang terjadi pada tahun 2001 profesi auditor menjadi sorotan utama terutama terkait dengan isu suap dan window dressing laporan keuangan. Penting sekali bagi 
auditor untuk tetap mempertahankan kepercayaan publik untuk menjaga eksistensi dan klien dari KAP sendiri. Semenjak kasus Enron, KAP Arthur Andersen sendiri telah dibubarkan dan kehilangan semua klien dan partner bisnis mereka.

Tentunya peranan auditor dan KAP sendiri menjadi semakin penting dan membutuhkan kepercayaan yang lebih tinggi setelah kasus tersebut. Di era globalisasi dan teknologi ini, hampir setiap tahun muncul bisnis-bisnis baru (start-up) yang mencari dana untuk pengembangan bisnis dan melahirkan bisnis-bisnis unik dan memberikan value added yang baik bagi masyarakat. Sehingga sekalipun sempat terganjal isu etika dan suap, sebenarnya bisnis konsultan ini masih sangat dibutuhkan oleh dunia bisnis. Hanya saja dalam praktiknya penting sekali untuk diberikan regulasi dan juga pengawasan yang baik supaya tidak terjadi hal menyimpang lagi seperti kasus Enron. Beranjak dari fenomena tersebut, maka penulis merasa penting sekali untuk memetakan kembali dan menelaah proses pengambilan keputusan hingga terbentuknya opini audit. Penulis sendiri ingin mencari tahu faktor apa saja yang bisa mempengaruhi terbentuknya opini audit. Apakah opini terbentuk karena adanya tekanan? Atau apakah opini terbentu karena adanya pengalaman mengaudit? Hasil kesimpulan yang diperoleh auditor lebih banyak dipengaruhi oleh faktor teknis ataukah non-teknis seperti jenis kelamin?

Oleh Karen itu penelitian ini mengambil focus untuk mengkaji judgement yang diberikan oleh seorang auditor terutama dalam aspek materialitas, risiko dan opini audit. Dalam prosesnya tentunya audit dipengaruhi oleh banyak faktor baik yang sifatnya teknis maupun non teknis. Untuk aspek teknis, beberapa hal seperti cara pandang auditor, risiko audit yang dihadapi auditor, tanggung jawab auditor, faktor pengetahuan, pengalaman, perilaku auditor dalam mengevaluasi informasi, kompleksitas pekerjaan dan tekanan baik dari klien maupun atasan turut mempengaruhi opini dari seorang auditor. Untuk faktor non teknis sendiri dipengaruhi oleh faktor demografik seperti jenis kelamin auditor itu sendiri. Hal ini tentunya sesuai dengan kajian penelitian oleh Chung dan Monroe (2001).

Penelitian ini dibuat untuk memetakan kembali faktor-faktor tersebut dengan tujuan mencoba mencari tahu bagaimana proses berpikir dan munculnya opini auditor. Hal ini dirasa penting karena profesi auditor sendiri sangat penting bagi penilaian bisnis serta penyajian laporan keuangan yang umumnya dipakai oleh 
para investor. Sampel dari penelitian ini adalah dari KAP kecil di daerah Tangerang. Setelah Sharon (2015) meneliti hal serupa di sebuah KAP wilayah Jakarta dan Tangerang penelitian kali ini mengambil sampel dengan skala yang lebih kecil dan perusahaan konsultan bisnis yang masih baru. Rumusan masalah penelitian ini adalah:

1. Apakah terdapat pengaruh pengalaman audit terhadap Audit Judgement di Kantor Konsultan Bisnis kecil?

2. Apakah terdapat pengaruh gender terhadap Audit Judgement di Kantor Konsultan Bisnis Kecil?

3. Apakah terdapat pengaruh Tekanan terhadap Audit Judgement di Kantor Konsultan Bisnis Kecil?

4. Apakah terdapat pengaruh Kompleksitas Tugas terhadap Audit Judgement di Kantor Konsultan Bisnis Kecil?

\section{TELAAH LITERATUR}

Arum (2008), menyatakan pengalaman audit merupakan ukuran sekaligus faktor pembentuk dari keahlian auditor. Sehingga berdasarkan pengalaman yang ada tentunya akan membentuk pola pikir serta pertimbangan (judgment) auditor. Dengan semakin banyak pengalaman di lapangan maka semakin banyak kasus yang ditangani sehingga auditor akan semakin mampu untuk mendeteksi kecurangan yang mungkin terjadi. Selain itu semakin banyak pengalaman semakin tinggi pula diharapkan tingkat akurasi pengerjaan auditor tersebut sehingga frekuensi kesalahan akan menurun. Yustrianthe (2012) malah menunjukkan hal kebalikannya yaitu pengalaman audit tidak berpengaruh terhadap audit judgement. Faktor pengalaman tidak berpengaruh dikarenakan variasi kasus yang cukup banyak sehingga auditor selalu menemukan kasus baru yang tidak bisa dijadikan acuan pengalaman dalam memberikan judgement.

Berninghausen dan Kerstan dalam Zulaikha (2006) menemukan bahwa gender juga dapat mempengaruhi judgement dari auditor. Peranan gender ini tidak hanya mengacu pada perbedaan biologis akan tetapi juga mencakup nilai social dan budaya setempat. Terutama di daerah timur yang sangat didominasi oleh para laki-laki hal ini bisa menyebabkan perbedaan audit judgement yang terjadi. Satu hal yang menarik dalam Kreitner dan Kinichi dalam Narsa (2006) adalah SexRole Stereotype yakni sebuah keyakinan bahwa sifat dan kemampuan antara lakilaki dan perempuan berbeda juga bisa membawa pada penilaian yang bias. Contoh umumnya adalah laki-laki secara 
tanpa kita sadari dinilai lebih objektif, independen, agresif dan memiliki kemampuan pertanggungjawaban yang lebih baik secara manajerial dibandingkan dengan perempuan. Perempuan sendiri dinilai lebih pasif, lembut dan berorientasi pada pertimbangan, sensitivitas dan lebih rendah posisinya

dalam pertanggungjawaban manajerial.

Praditaningrum dan Januarti (2012) menunjukkan bahwa gender berpengaruh signifikan terhadap audit judgment. Akan tetapi hasil penelitian ini tidak sejalan dengan hasil penelitian Jamilah, et al. (2007) yang menyatakan hal sebaliknya.

Tekanan juga menjadi salah satu faktor yang berpengaruh terhadap audit judgment. Tentunya hal ini dipicu oleh tekanan oleh atasan ataupun klien dalam kondisi-kondisi tertentu yang diinginkan oleh mereka. Tentunya hal ini menjadi sebuah dilemma bagi para auditor karena hal seperti ini yang mendorong terjadinya suap dan penipuan. Tekanan yang dibahas pada penelitian ini lebih ke arah ketaatan pada otoritas yang lebih tinggi. Milgram dalam Jamilah (2007) menjelaskan paradigm ketaatan pada otoritas kekuasaan dikarenakan oleh rasa takut ataupun posisi tawar yang lebih rendah. Dalam teori tersebut seorang bawahan yang mengalami tekanan ketaatan karena atasan maka mengalami perubahan psikologis dari seseorang yang berperilaku atas dirinya sendiri menjadi perilaku agen. Perilaku agen ini adalah perilaku yang turut pada instruksi dari atasan atau pemberi perintah. Perubahan perilaku ini terjadi dipicu karena bawahan tersebut merasa menjadi agen dari sumber kekuasaan, dan akibatnya dirinya merasa terlepas dari tanggung jawab atas apa yang dilakukannya dan merasa aman karena memang hal itu yang diinginkan oleha atasannya. Tekanan yang umumnya diterima auditor juga bisa berasal dari klien. Teori ketaatan menyatakan bahwa individu yang memiliki kekuasaan merupakan suatu sumber yang dapat mempengaruhi perilaku orang lain dengan perintah yang diberikan. Akibatnya auditor yang tadinya memiliki prinsip yang baik serta penilaian yang salah akan merasa berada dibawah tekanan dan menunjukkan perilaku dysfunctional. Hasil akhirnya adalah auditor cenderung menyetujui kesalahan yang dibuat oleh kliennya sekalipun menyadari kesalahan tersebut. Praditaningrum dan Januarti (2012) juga masih menunjukkan bahwa tekanan ketaatan tersebut tentunya berpengaruh terhadap audit judgment.

Faktor Kompleksitas tugas juga berpengaruh pada Audit Judgement yang dibuat oleh auditor. Semakin tinggi kompleks penugasan yang diterima auditor 
maka semakin banyak pula aspek yang harus ia pikirkan terkait tugas tersebut. Stuart (2001) menyatakan bahwa semakin kompleks tugas yang dihadapi oleh seorang auditor maka akan semakin sulit baginya untuk memberikan penilaian yang cepat dan akurat. Dibutuhkan kehati-hatian serta banyak pertimbangan sebelum membuat opini audit ataupun judgement. Jamilah et al. (2007) menyatakan tingkat kesulitan tugas dan struktur tugas merupakan dua aspek penyusun dari kompleksitas tugas. Tingkat sulitnya tugas selalu dikaitkan dengan banyaknya informasi tentang tugas tersebut, sementara struktur adalah terkait dengan kejelasan informasi (information clarity). Sanusi dan Iskandar (2007), peningkatan usaha dari seorang individu dapat berdampak secara langsung dan lebih signifikan terhadap efektifitas individu dalam menjalankan tugas-tugas dengan tingkat kompleksitas yang rendah. Sebaliknya, apabila tugas tersebut memiliki tingkat kompleksitas yang tinggi serta tidak terstruktur maka usaha yang lebih pun mungkin tidak mampu lagi memfasilitasi pencarian auditor dalam keberhasilan penyelesaian tugasnya. Semakin diperlukan banyak usaha dan kompleks suatu tugas maka semakin banyak sumber daya yang digunakan dan juga lama wkatu yang diperlukan auditor untuk menyesaikan pekerjaannya. Selain itu waktu yang lama tidak menjamin hasil yang lebih akurat dari penilaian tersebut. Yustrianthe (2012) juga menyatakan bahwa kompleksitas tugas berpengaruh signifikan terhadap audit judgment. Namun sangat berbeda dengan hasil penelitian Jamilah, et al. (2007) yang menyatakan bahwa situasi tugas yang kompleks tidak mempengaruhi pengambilan audit judgment.

Penelitian ini mengacu kepada penelitian Sharon (2015) yang meneliti pengaruh variabel gender, tekanan ketaatan dan kompleksitas tugas terhadap audit judgment pada KAP di daerah Tangerang dan Jakarta. Penelitian ini adalah kelanjutan dari penelitian tersebut dengan pendekatan dan kriteria sampel yang berbeda. Dengan demikian diharapkan penelitian ini dapat memberikan tambahan bukti empiris terhadap audit judgement yang terjadi pada kantor KAP kecil. Harapan penulis adalah pada KAP kecil, faktor yang mempengaruhi audit judgement adalah faktor yang sama pada KAP besar lainnya. Selain itu diharapkan penelitian ini bisa menjadi bukti pendukung literature akuntansi dan memberikan kontribusi terhadap teori akunansi. 
Hipotesis penelitian ini adalah sebagai berikut:

$\begin{aligned} \mathrm{H}_{\mathrm{a} 1} \quad: & \text { Terdapat pengaruh } \\ & \text { pengalaman audit terhadap } \\ & \text { Audit Judgement di Kantor } \\ & \text { Konsultan Bisnis kecil? } \\ \mathrm{H}_{\mathrm{a} 2} \quad: & \text { Terdapat pengaruh gender } \\ & \text { terhadap Audit Judgement di } \\ & \text { Kantor Konsultan Bisnis } \\ & \text { Kecil? }\end{aligned}$

$\mathrm{H}_{\mathrm{a} 3} \quad$ : Terdapat pengaruh Tekanan terhadap Audit Judgement di Kantor Konsultan Bisnis Kecil?

$\mathrm{H}_{\mathrm{a} 4} \quad$ : Terdapat pengaruh Kompleksitas Tugas terhadap Audit Judgement di Kantor Konsultan Bisnis Kecil?

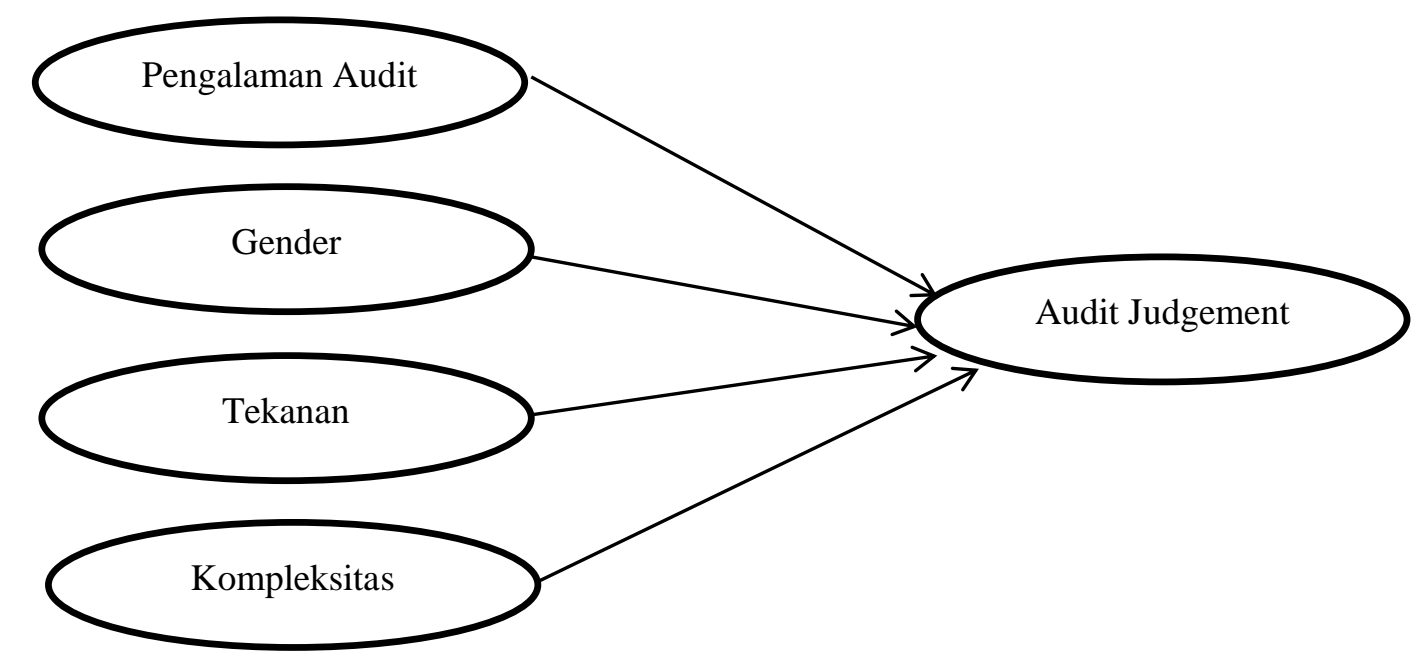

Gambar 1. Kerangka Penelitian

\section{METODOLOGI PENELITIAN}

Penelitian ini akan dianalisis dengan menggunakan regresi linear berganda. Setiap variable penelitan akan diuji validitas dan reliabilitasnya terlebih dahulu sebelum dilakukan uji regresi. Penyebaran kuisioner hanya terbatas pada sebuah kantor KAP di daerah Tangerang. Metode pengambilan sampel adalah purposive sampling. Setelah dilakukan uji validitas dan reliabilitas maka dilakukan juga uji normalitas. Jika semua kondisi sudah dipenuhi maka penulis melanjutkan ke proses uji asumsi klasik yang mencakup uji multikolinearitas, uji heteroskedastisitas dan uji autokorelasi. Setelah uji asumsi klasik lolos, maka dilakukan uji $\mathrm{F}$, uji $\mathrm{t}$ dan uji koefisien 
determinasi. Sehingga dengan demikian kita dapat memperoleh esensi dari audit judgement terutama pada perusahaan yang bleum establish cukup lama.
Berikut ini adalah hasil paparan sebaran sampel penelitian yang telah berhasil diperoleh dalam penelitian ini. Total sampel yang diambil adalah 35 responden kuisioner.

\section{HASIL \& ANALISIS}

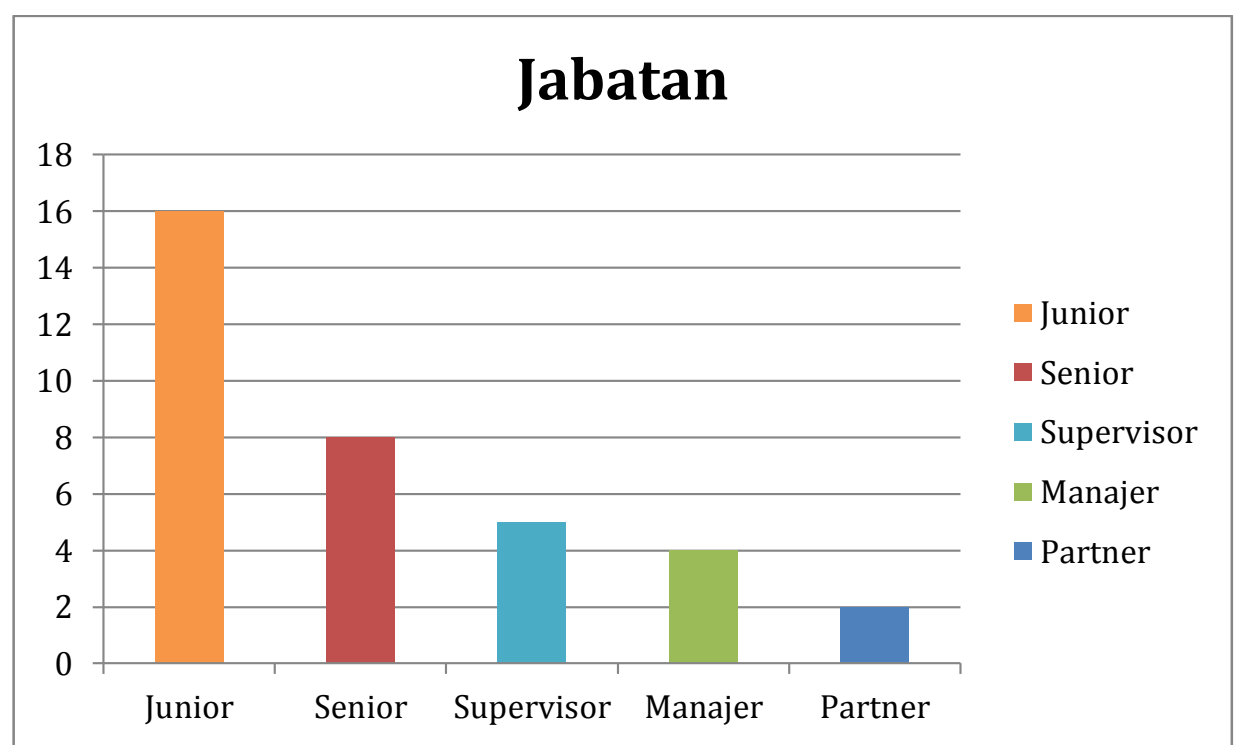

Gambar 2. Sebaran Jabatan Responden Penelitian

Dalam kantor konsultan bisnis yang sebagai junior auditor di kantor tersebut. dijadikan sampel dalam penelitian ini, Selain itu mereka juga termasuk anak-anak hampir sebagian besar profil jabatan magang dari Universitas di daerah pengisi kuisioner adalah Junior. Terdapat Tangerang. Untuk jabatan tertinggi adalah sekitar 16 responden yang berpangkat Partner dengan jumlah 2 orang.

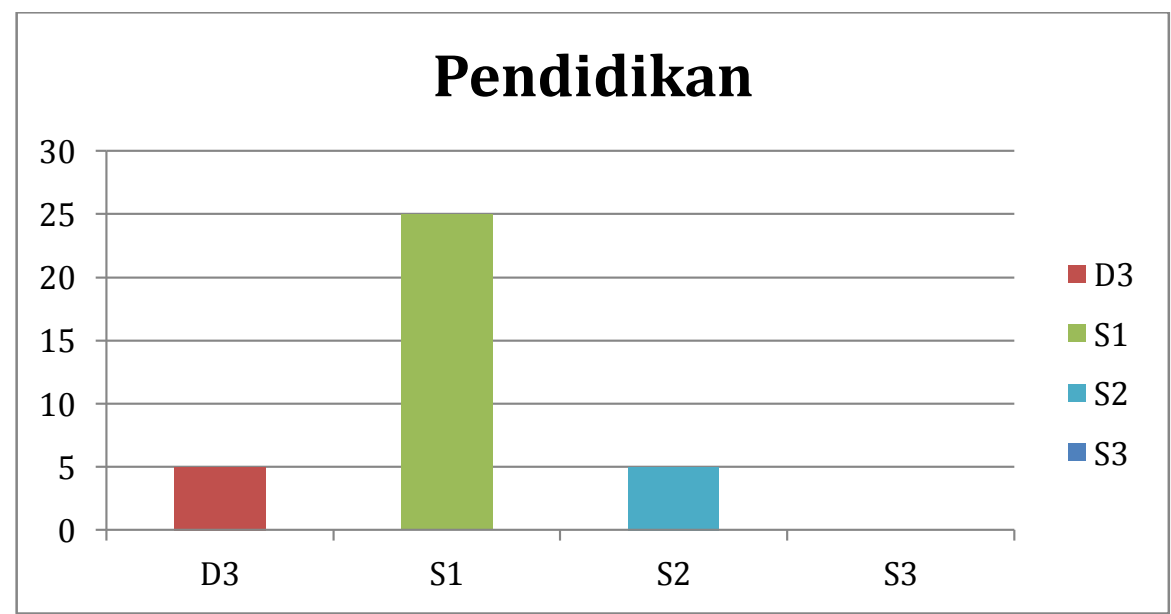

Gambar 3. Profil Pendidikan Responden Penelitian 
Sedangkan untuk profil pendidikan responden, sebagian besar adalah lulusan S1 dan terdapat beberapa responden yang masih kuliah sebanyak 5 orang. Untuk responden dengan level manajer dan Partner hampir sebagian besar adalah lulusan S2. Dalam penelitian ini tidak ada responden dengan tingkat pendidikan $\mathrm{S} 3$.

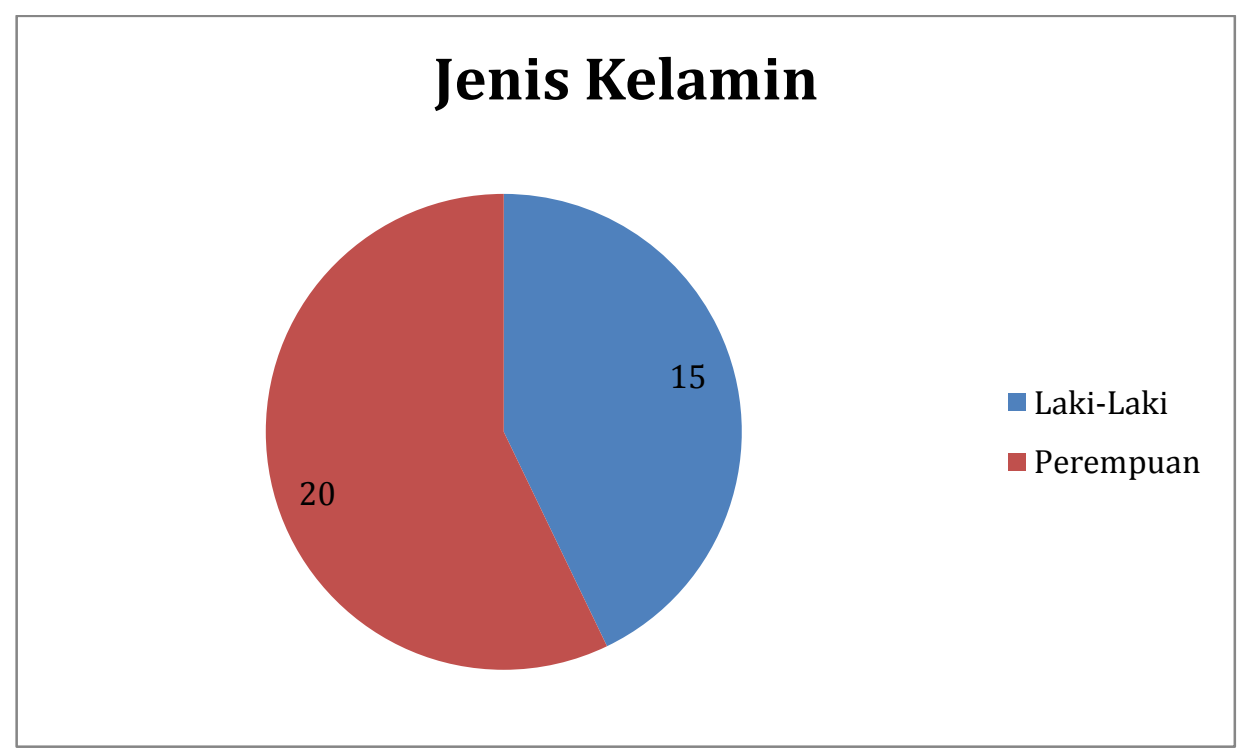

Gambar 4. Jenis Kelamin Responden Penelitian

Untuk profil jenis kelamin dari responden, perempuan dan 15 responden berjenis ada 20 responden berjenis kelamin kelamin laki-laki.

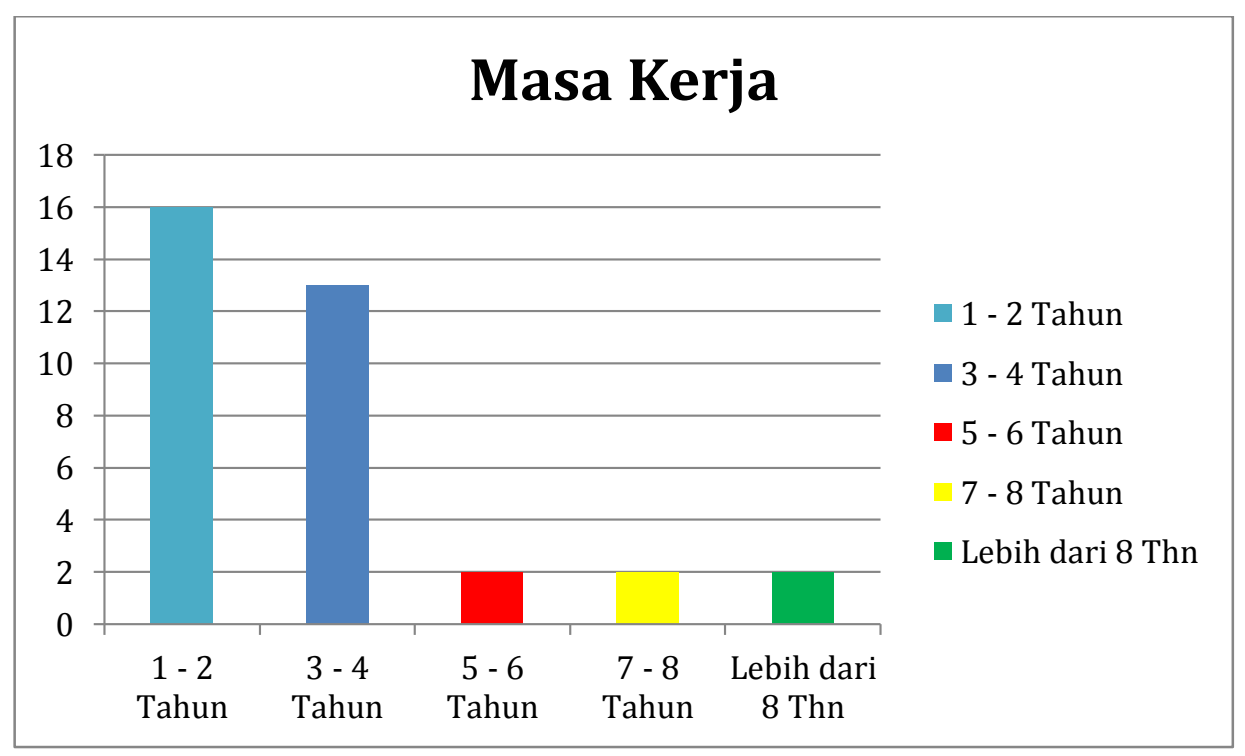

Gambar 5. Deskripsi Masa Kerja Responden 
Sedangkan untuk sebaran masa kerja responden, dikarenakan hampir sebagian besar responden adalah junior auditor maka temuan masa kerja mereka juga hampir sebagian besar di antara $1-2$ tahun kerja. Terdapat 16 responden dengan masa kerja tersebut. Sedangkan untuk 2 orang partner, memiliki masa kerja yang telah lebih dari 8 tahun.

Sebelum melakukan uji terhadap hipotesis penelitian, maka terlebih dahulu peneliti melakukan uji validitas dan reliabilitas. Uji validitas dan reliabilitas dilakukan dengan menggunakan SPSS 22.

Tabel 1. Hasil Tes Reliability

\begin{tabular}{lr}
\hline Variabel & Cronbach's Alpha \\
\hline Kompleksitas & 0.953 \\
Tekanan & 0.896 \\
Audit Judgement & 0.940 \\
\hline
\end{tabular}

Hasil dari Reliability Test menunjukan nilai indicator Cronbach's Alpha yang sangat baik. Ketiga instrument pertanyaan pada kuisoner sangat reliable dalam mencerminkan variabel penelitian. Hal ini tercermin pada nilai Cronbach's Alpha yang lebih dari 0.5. Semua instrument variabel penelitian memiliki nilai Cronbach's Alpha lebih dari 0.5.

Tabel 2. Hasil Tes Validitas

\begin{tabular}{llllll}
\hline $\begin{array}{l}\text { Indikator } \\
\text { Kuisioner }\end{array}$ & $\begin{array}{l}\text { Nilai Pearson } \\
\text { Correlation }\end{array}$ & $\begin{array}{l}\text { Indikator } \\
\text { Kuisoner }\end{array}$ & $\begin{array}{l}\text { Nilai Pearson } \\
\text { Correlation }\end{array}$ & $\begin{array}{l}\text { Indikator } \\
\text { Kuisoner }\end{array}$ & $\begin{array}{l}\text { Nilai Pearson } \\
\text { Correlation }\end{array}$ \\
\hline K1 & $0.913^{* *}$ & T1 & $0.623^{* *}$ & AJ1 & $0.587^{* *}$ \\
K2 & $0.859^{* *}$ & T2 & $0.383^{*}$ & AJ2 & $0.726^{* *}$ \\
K3 & $0.849^{* *}$ & T3 & $0.872^{* *}$ & AJ3 & $0.837^{* *}$ \\
K4 & $0.808^{* *}$ & T4 & $0.543^{* *}$ & AJ4 & $0.848^{* *}$ \\
K5 & $0.936^{* *}$ & T5 & $0.890^{* *}$ & AJ5 & $0.897^{* *}$ \\
K6 & $0.838^{* *}$ & T6 & $0.896^{* *}$ & AJ6 & $0.875^{* *}$ \\
& & T7 & $0.821^{* *}$ & AJ7 & $0.835^{* *}$ \\
& & T8 & $0.724^{* *}$ & AJ8 & $0.814^{* *}$ \\
& & T9 & $0.436^{* *}$ & AJ9 & $0.606^{* *}$ \\
& & & & AJ10 & $0.782^{* *}$ \\
\hline
\end{tabular}

Hasil uji validitas menggunakan indikator korelasi dari pearson correlation. Hasil menunjukan secara konsisten nilai pearson correlation signifikan sehingga dapat dikatakan instrument kuisoner sangat valid dalam penelitian ini. Setiap tanda $(*)$ menunjukan terdapat cukup bukti menunjukan adanya hubungan yang erat 
antara pertanyaan kuisioner dengan distribusi normal. Untuk uji variabel yang diteliti.

multikolinearitas penelitian ini Setelah dilakukan uji validitas dan menggunakan nilai VIF untuk sebagai reliabilitas maka selanjutnya dilakukan uji indikator. Untuk uji heteroskedastisitas asumsi klasik yang mencakup uji penelitian ini menggunakan gambar normalitas, multikolinearitas, sebaran residual sebagai indikator. Dan heteroskedastisitas, dan juga uji untuk uji autokorelasi penelitian ini autokorelasi. Untuk uji normalitas menggunakan Durbin Watson Statistik tes penelitian ini menggunakan gambar sebagai indikator.

sebaran residual dengan histogram

Tabel 3. Hasil Uji Multikolinearitas dan Autokorelasi

\begin{tabular}{ll}
\hline Indikator & Nilai \\
\hline VIF Pengalaman Audit & 3.854 \\
VIF Gender & 1.167 \\
VIF Tekanan & 4.656 \\
VIF Kompleksitas & 3.006 \\
DW Stats & 2.073 \\
\hline
\end{tabular}

Berdasarkan hasil uji VIF dan itu terdapat cukup bukti untuk Autokorelasi, tidak ditemukan adanya membuktikan dalam penelitian variabel indikasi penyimpangan dari uji asumsi bebas penelitian tidak mengalami masalah klasik. Nilai VIF tidak lebih dari 10 dan uji asumsi klasik. juga nilai DW Stats sebesar 2. Oleh karena

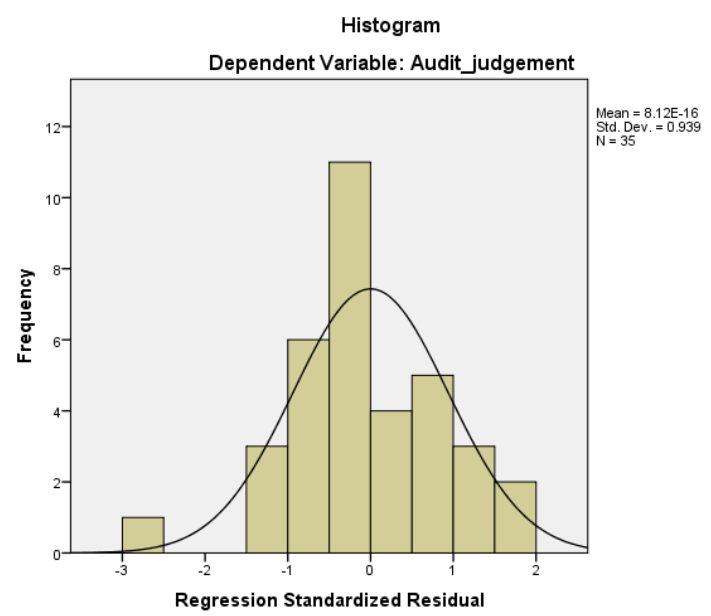

Gambar 6. Histogram Residual 
Dari Gambar 6 di atas, distribusi residual dari persamaan regresi yang terbentuk membentuk bells shape. Oleh karena itu dapat dikatakan persamaan regresi memiliki residual yang tersebar merata (homogen) dan juga dapat disimpulkan terdistribusi normal karena membentu bells shape.

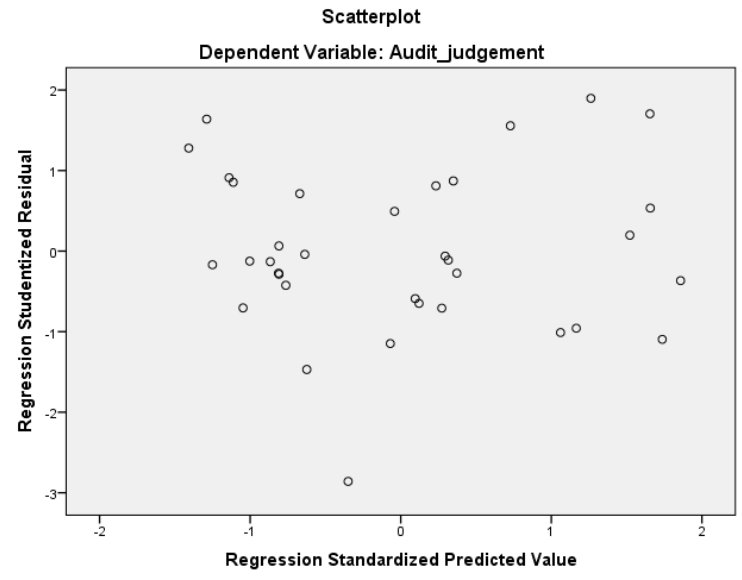

Gambar 7 Sebaran Residual untuk uji Heteroskedastisitas

Pada gambar 7 dapat terlihat sebaran residual tersebar merata. Tidak terbentuk pola tertentu dari variabel penelitian ini, sehingga dapat disimpulkan tidak terjadi masalah heteroskedastisitas dalam penelitian ini.

Setelah semua variabel penelitian terbebas dari indikasi kesalahan akibat gagalnya

Tabel 4. Hasil uji F, t dan nilai Koefisien Determinasi

\begin{tabular}{lrrr}
\hline Variabel & Unstd Coeficient & $\mathrm{t} / \mathrm{F}$ & $\mathrm{p}$ Value / Nilai R \\
\hline Constant & 3.591 & 3.644 & 0.001 \\
Pengalaman Audit & 0.267 & 3.142 & 0.004 \\
Gender & 0.187 & 1.638 & 0.113 \\
Tekanan & -5.999 & -2.903 & 0.007 \\
Kompleksitas & 0.142 & 1.504 & 0.143 \\
F test & & 51.167 & 0.000 \\
Adj R & & & 0.855 \\
\hline
\end{tabular}

Berdasarkan hasil uji F, maka dapat dilihat nilai $\mathrm{p}$ value adalah 0.000 . Hipotesis untuk uji $\mathrm{F}$ adalah secara simultan, Pengalaman audit, Gender, Tekanan dan Kompleksitas memenuhi uji asumsi klasik, maka penelitian ini melanjutkan dengan uji $\mathrm{F}$ dan uji t untuk setiap variabel bebas penelitian. Tabel berikut ini berisi hasil ringkasan hasil uji $\mathrm{F}$ dan uji t penelitian. 
bahwa secara simultan terdapat pengaruh Pengalaman audit, Gender, Tekanan dan Kompleksitas terhadap Audit Judgement.

Selain itu untuk memberikan hasil yang lebih tajam, uji t dilakukan untuk menguji pengaruh variabel bebas secara parsial. Jika nilai $\mathrm{p}$ value $<0.05$ maka dapat disimpulkan terdapat pengaruh variabel bebas secara parsial terhadap variabel terikat.

Dari tabel di atas terlihat nilai $\mathrm{p}$ value yang $<0.05$ ada pada variabel Pengalaman Audit dan Tekanan. Sedangkan untuk Gender dan Kompleksitas Tugas tidak mempengaruhi Audit Judgement dari auditor itu sendiri.

Untuk pembahasan, Gender tidak berpengaruh terhadap audit judgement dikarenakan tidak ada superioritas di KAP yang dijadikan sampel penelitian. Hal ini tentunya sejalan dengan penelitian yang terdahulu yang menemukan jika terjadi budaya superioritas laki-laki karena adanya faktor budaya wilayah tertentu sehingga ditemukan pengaruh Gender terhadap Audit Judgement maka pada penelitian ini mengkonfirmasi karena tidak terjadinya hal tersebut di kantor sampel maka tidak ada pengaruh Gender dalam audit judgement.
Masalah kompleksitas tugas yang diberikan, jika ditelaah baik dari sisi senior, partner dan juga junior telah mendapatkan porsi kerjaan dan tugas yang sesuai dengan kapasitas mereka masingmasing. Oleh karena itu baik dari sisi junior tidak merasa adanya kasus yang sangat kompleks yang jauh dari kapasitas mereka. Oleh karena itu tidak ditemukan pengaruh Kompleksitas terhadap audit judgement. Hal ini mungkin akan terjadi ketika atasan mulai memberikan tantangan ataupun membagikan tanggung jawab yang cukup rumit untuk dipegang oleh junior. Dalam praktiknya pada KAP Big 4, memang hal ini umum terjadi untuk menantang dan menjadi pengukur kapabiltas junior, akan tetapi tidak demikian budaya pada kantor konsultan kecil. Di sisi lain, untuk kasus yang rumit juga masih bisa dihandle oleh level manajer dan partner sehingga semua pihak mendapatkan tanggung jawab yang sesuai dengan kemampuan mereka masingmasing.

Yang menarik untuk dibahas adalah pengaruh faktor tekanan. Tekanan ketaatan pada kasus ini memberikan hasil yang negative. Terdapat pengaruh negative tekanan ketaatan terhadap audit judgement di kantor ini. Pengaruh negatif ini berarti semakin tidak taat maka semakin positif 
audit judgement yang terjadi. Jika membedah sampel penelitian maka memang ditemukan hampir sebagian besar yang terdiri atas junior lebih sering untuk taat pada tekanan yang terjadi. Akan tetapi pada level supervisor ke atas, kecenderungan mereka adalah lebih professional dan menentang beberapa hal yang tidak sesuai dengan etika dan nilai profesionalitas mereka. Oleh karena itu semakin para high level berani untuk tidak taat dan takut pada tekanan, maka audit judgement yang mereka buat semakin positif ataupun semakin mendekati informasi yang sejujur-jujurnya.

Faktor terakhir membuktikan juga ada hubungan antara pengalaman audit dengan audit judgement. Tentunya dengan semakin tinggi jam terbang dan pengalaman maka semakin tajam dan jeli kemampuan analisa dan mendeteksi kecurangan yang mungkin terjadi. Dari hasil penelitian ini terbukti pada high level mereka lebih cenderung berhati-hati dan memberikan opini apa adanya.

\section{KESIMPULAN}

Berdasarkan hasil temuan penelitian ini, peneliti menyimpulkan bahwa tidak terdapat pengaruh faktor gender dan juga kompleksitas pekerjaan dalam pemberian audit judgement seorang auditor. Akan tetapi penelitian ini membuktikan terdapat pengaruh faktor tekanan dan pengalaman kerja terhadap audit judgement. Faktor tekanan yang mengacu kepada ketaatan terbukti memiliki hubungan yang negatif. Semakin seorang auditor tidak taat, maka semakin baik (positif) audit judgement yang diberikan oleh seorang auditor. Kecenderungan ini juga baru ditemukan pada top level manajemen dari sebuah kantor konsultan bisnis. Selain itu faktor pengalaman kerja juga memberikan wawasan, variasi kasus yang tinggi bagi para top level sehingga mereka lebih cenderung bisa memecahkan masalah dari klien bisnis sesuai dengan penyelesaian masalah yang telah pernah mereka lakukan selama bekerja. Akan tetapi memang skill ini masih belum ada pada level junior dikarenakan rendahnya jam terbang dan juga rendahnya variasi pekerjaan yang mereka terima.

Dengan demikian penelitian ini ingin menggarisbawahi beberapa hal yang cukup penting untuk menjadi perhatian kantor konsultan bisnis:

Pentingnya pemberian variasi tugas bagi level junior dan senior, sehingga para junior dan senior bisa belajar lebih banyak dari variasi kasus dan diharapkan memberikan judgement yang lebih akurat dan mendekati realitas yang ada. 
Kecenderungan level rendah adalah taat.

Oleh karena itu sebagai atasan penting sekali untuk memastikan mereka belajar bersikap professional dari dini. Jika diarahkan dengan baik oleh atasan maka bisa jadi mereka juga pada akhirnya membawa nilai etika yang baik di masa yang akan datangnya.

Tidak terdapat pengaruh gender merupakan hal yang sangat baik karena adanya ekualitas antara laki-laki dan perempuan. Hal ini kiranya tetap bisa dipertahankan.

Untuk perusahaan konsultan bisnis kecil, memang dibutuhkan kecepatan dan fleksibilitas dalam menangani klien kecil dan menengah. Penting sekali pihak petinggi perusahaan telah memberikan standard etika profesi dan juga pedoman dalam memberikan audit judgement sehingga mereka bisa memberikan layanan optimal tanpa harus adanya penyimpangan perilaku dan etika.

\section{DAFTAR PUSTAKA}

Ardiyos. 2008. Kamus Besar Akuntansi, Jakarta: Citra Harta Prima.

Arum, Enggar Diah Puspa. 2008. Pengaruh Persuasi atas Preferensi Klien dan Pengalaman Audit Terhadap Pertimbangan Auditor dalam Mengevaluasi Bukti Audit. Jurnal Akuntansi dan Keuangan Indonesia, Vol. 5, No. 2 Desember 2008.
Arens,Alvin, Elder, Randal J. dan Beasley, Mark S. 2006. Auditing dan Pelayanan Verifikasi Pendekatan Terpadu. Edisi 9. Jilid 2. Jakarta : PT. Indeks.

Agoes, Sukrisno dan Hoesada, Jan. 2009. Bunga Rampai Auditing. Jakarta: Salemba Empat.

Chung, J. dan Monroe, G.S., 2001., A Research Note on The Effect of Gender and Task Complexity on Audit Judgment., Journal of Behavioral Research., 13:111125.

Febrianty. 2012. Pengaruh Profesional Auditor terhadap Pertimbangan Tingkat Materialitas Audit atas Laporan Keuangan. Jurnal Ekonomi dan Informasi Akuntansi (JENIUS), Vol.2 No.2., hal. 191.

Ghozali, Imam. 2012. Aplikasi Analisis Multivariate dengan Program IBM SPSS 20 Edisi 6. Semarang: Badan Penerbit Universitas Diponegoro.

Hamdani, Yusron. 2012. "Pengaruh Gender, Tekanan Ketaatan, dan Kompleksitas Tugas Terhadap Audit Judgment (Studi Pada Kantor Akuntan Publik di Jawa Tengah)." Disertasi Doktoral, Universitas Muhammadiyah Surakarta.

Hartanto, Hansiadi Yuli dan Kusuma, Indra Wijaya. 2001. "Analisis Pengaruh Tekanan Ketaatan Terhadap Judgment Auditor". Jurnal Akuntansi dan Manajemen. Ed. Desember, hal 1-14. 
Hidayati, Fitria. 2012. "Pengaruh Gender, Tekanan Ketaatan, Kompleksitas Tugas, Dan Pengalaman Auditor Terhadap Audit Judgment (Studi Empiris Pada Kantor Akuntan Publik Di Surakarta Dan Yogyakarta)." Disertasi Doktoral, Universitas Muhammadiyah Surakarta.

Ikatan Akuntan Indonesia. 2011. "Standar Profesional Akuntan Publik". Jakarta: Salemba Empat.

Jamilah. S., Zaenal Fanani dan Chandrarin, Grahita. 2007. "Pengaruh Gender Tekanan Ketaatan dan Kompleksitas Tugas Terhadap Audit Judgment" SNA X, Makassar, 26-28 Juli 2007.

Kusuma, Novanda , Aji, Friska Bayu. 2012. "Pengaruh Profesionalisme Auditor, Etika Profesi dan Pengalaman Auditor terhadap Pertimbangan Tingkat Materialitas". Skripsi, Fakultas Ekonomi Universitas Negeri Yogyakarta.

Narsa, I Made. 2006. "Sex-Role Stereotype dalam Rekrutmen Pegawai Akuntansi dan Keuangan: Observasi terhadap Pola Rekruitmen Terbuka di Media Masa".

Neueldt, Victoria dan Guralnik, David B. 1991. Webster's New World Dictionary of American English, 3rd College Edition. New York: Prentice Hall.
Praditaningrum dan Januarti. 2012. Analisis Faktor-faktor yang Berpengaruh Terhadap Audit Judgment (Studi Pada BPK RI Perwakilan Provinsi Jawa Tengah). Skripsi Universitas Diponegoro.

Sabaruddinsah. 2012. "Pengaruh Gender, Pengalaman Auditor, dan Kompleksitas Tugas Terhadap Audit Judgement". Jurnal LPPM: PARADIGMA 8, no. 01.

Sanusi, M., Zuraidah dan Iskandar, Takiah Mohd. 2007. "Audit Judgment Performance: Assessing The Effect Of Performance Incentives, Effort and Task Complexity". Managerial Auditing Journal. Vol. 22, No. 1, pp 34-52.

Sekaran, Uma. 2010. Research Methods for Business, New York: John Wiley and Sons, Ltd, Publication.

Stuart, I., 2001., The Influence of Audit Structure on Auditor Performance in High and Low Complexity Task Setting. Journal of Accounting Behavior.,3-30.

Suraida, Ida. 2005. "Pengaruh Etika, Kompetensi, Pengalaman Audit dan Risiko Audit terhadap Skeptisisme Profesional Auditor dan Ketepatan Pemberian Opini Akuntan Publik." Sosiohumaniora. Vol.7, No.3.

Susanti, Novarina Cinde. 2010. "Pengaruh Gender, Kompleksitas Tugas, dan Kompetensi Auditor Terhadap Audit Judgment: Studi Empiris Pada Kantor Akuntan Publik di Jakarta." 
Tielman, Elisabeth Mariana Andita, dan Pamudji, Sugeng. 2012. Pengaruh Tekanan Ketaatan, Tekanan Anggaran Waktu, Kompleksitas Tugas, Pengetahuan dan Pengalaman Auditor terhadap Audit Judgment. Disertasi Doktoral Fakultas Ekonomika dan Bisnis Universitas Diponegoro.

Tobing, Melthakasih L. 2013. "Pengaruh Gender, Tekanan Ketaatan, Kompleksitas Tugas dan Pengalaman Auditor terhadap Audit Judgment Badan Pemeriksa Keuangan (BPK) RI Perwakilan Provinsi Riau".

Tuanakotta, Theodorus M. 2011. "Berpikir Kritis Dalam Auditing”, Jakarta: Penerbit Salemba Empat.
Wibowo Ery. 2011. Analisis Pembelajaran Mata Kuliah Auditing (Kompetensi dalam Auditor Judgement). Jurnal MAKSIMUM, Vol.1, No.2 Maret 2011.

Yustrianthe, Rahmawati Hanny. 2012. Beberapa Faktor Yang Mempengaruhi Audit Judgment Auditor Pemerintah. Jurnal Dinamika Akuntansi Vol.4, No.2, 72-82.

Yuliani, Nur Laila. 2012. Pressure of Compliance, Task Complexity, Independence, Knowledge, and Experience on Auditors Audit Judgment. Jurnal Fakultas Ekonomi 10, no.1, 40-53.

Zulaikha. 2006. "Pengaruh Interaksi Gender, Kompleksitas Tugas, dan Pengalaman Auditor Terhadap Audit Judgment". Simposium Nasional Akuntansi 9 Padang. 